\title{
Rethinking Corporate Agency in Business, Philosophy, and Law
}

\author{
Samuel Mansell ${ }^{1} \cdot$ John Ferguson $^{1} \cdot$ David Gindis $^{2} \cdot$ Avia Pasternak $^{3}$
}

Received: 17 April 2018 / Accepted: 19 April 2018 / Published online: 28 April 2018

(c) Springer Science+Business Media B.V., part of Springer Nature 2018

\begin{abstract}
While researchers in business ethics, moral philosophy, and jurisprudence have advanced the study of corporate agency, there have been very few attempts to bring together insights from these and other disciplines in the pages of the Journal of Business Ethics. By introducing to an audience of business ethics scholars the work of outstanding authors working outside the field, this interdisciplinary special issue addresses this lacuna. Its aim is to encourage the formulation of innovative arguments that reinvigorate the study of corporate agency and stimulate further cross-fertilization of ideas between business ethics, law, philosophy, and other disciplines.
\end{abstract}

Keywords Group agent · Corporate agency · Corporate personhood · Corporate rights · Corporate responsibility Collective responsibility

\section{Introduction}

Should we attribute agency exclusively to individuals, or can it also be a property of organized groups such as business corporations and states? If "corporate agents" exist, do they, and should they, have the same rights and responsibilities as individual human beings? What are the most suitable means for holding corporate agents responsible? How should responsibility for corporate misbehavior be shared among the human beings involved? And how should responsibility for collective harm be shared within groups of individuals that do not qualify as corporate agents?

Samuel Mansell

sfm5@st-andrews.ac.uk

John Ferguson

jf60@st-andrews.ac.uk

David Gindis

d.gindis@herts.ac.uk

Avia Pasternak

avia.pasternak@ucl.ac.uk

1 School of Management, University of St. Andrews, The Gateway, North Haugh, St. Andrews, Fife KY16 9RJ, UK

2 Hertfordshire Business School, University of Hertfordshire, Hatfield, Hertfordshire, UK

3 Department of Political Science, University College London, Gower Street, London WC1E 6BT, UK
A rich literature in business ethics, moral philosophy, and jurisprudence is devoted to these fundamental questions of social ontology and their normative implications. But, with some notable exceptions (e.g., Orts and Smith 2017), there have been relatively few attempts to bring together insights from these and other disciplines. Certainly, such attempts have been scarce in the Journal of Business Ethics. This special issue addresses this lacuna, in line with the recognition that ground-breaking ideas are likely to be interdisciplinary in nature (Arnold et al. 2016) and the ambition to broaden the intellectual base of business ethics scholarship (Greenwood and Freeman 2017).

The proposal for this special issue arose from a conference on "Corporate Agency and Shared Responsibility" hosted by the University of St. Andrews (St. Andrews, UK) in November 2015, and a symposium on "The Nature and Governance of the Corporation" organized by the World Interdisciplinary Network for Institutional Research at the Università della Svizzera italiana (Lugano, Switzerland) in April 2015. At these events participants drew on perspectives from across the humanities and social sciences to rethink the concepts of corporate agency, collective responsibility, and the nature of the corporation itself. Our aim here is to continue this dialogue between disciplinary perspectives in order to broaden and deepen the debate on corporate agency.

Among business ethicists, the proposition that corporations are moral agents is a long-established topic of 
controversy and debate (e.g., French 1979; De George 1981; Donaldson 1982; Goodpaster and Matthews 1982; Velasquez 1983; Werhane 1985; May 1987; Pfeiffer 1990). A consensus has not been reached, and while interest in the subject has somewhat subsided (Moriarty 2016), it has not disappeared (e.g., Moore 1999; Danley 1999; Velasquez 2003; Altman 2007; Ashman and Wistanley 2007; Watson et al. 2008; Dubbink and Smith 2011; Dempsey 2013; Rönnegard 2013; Lampert 2016; Bowie 2017; Burt and Mansell 2017).

The subject has received a great deal of attention from moral philosophers. Alongside work that considers the very possibility of corporate moral agency and responsibility (e.g., Wellman 1995; Gilbert 2002; Miller and Makela 2005; Copp 2006; Isaacs 2011; List and Pettit 2011; Preda 2012), the ethical implications of corporate responsibility, including the appropriate responses to a delinquent corporate agent (e.g., Erskine 2011; Wringe 2012) and the distribution of responsibility within corporate agents (e.g., Held 2002; Pasternak 2011; Stilz 2011), have been debated. But the recent controversy surrounding the U.S. Supreme Court's rulings in Citizens United ${ }^{1}$ and Hobby Lobby ${ }^{2}$ — which extended First Amendment protections to corporations-has brought an additional set of questions to the center stage.

In what legal sense are corporations "persons"? Why has law assigned rights and responsibilities to corporate persons, and do these really belong to corporate persons qua corporate persons? How are these connected with individual moral rights and responsibilities? These questions have a long intellectual history (Canning 1996; Runciman 1997; Black 2002; Turner 2016). They were a hot topic among jurists at the turn of the twentieth century (e.g., Freund 1897; Gierke 1900; Maitland 1905; Deiser 1909; Machen 1911; Laski 1916), and are now making a comeback (e.g., Pollman 2011; Blair 2013; Coleman 2014; Greenfield 2015; Piety 2015; Gindis 2016; Robinson 2016; Greenwood 2017; Kurki and Pietrzykowski 2017) against a backdrop of widespread calls to restrict constitutional rights to human beings (Ripken 2011).

The extension of constitutional rights to corporate persons has been identified among the critical events in the history of the corporate form with immediate relevance for business ethics (Beets 2011). However, a survey of the leading journals in the field reveals that very little has been written on the topic. There has been an interest in the implications of Citizens United in terms of corporate political influence, which speaks to the familiar theme of the corporation's role or place in society (e.g., Silver 2015; Stoll 2015; Néron 2016). Nonetheless, most of the articles connecting the issue

${ }^{1}$ Citizens United v. Federal Election Commission, 558 U.S. 310 (2010).

2 Burwell v. Hobby Lobby Stores Inc., 134 S. Ct. 2751 (2014). of corporate personhood with ethical considerations pre-date the Citizens United case (e.g., Manning 1984; Phillips 1992; Stoll 2005; Ayer 2006; Pettit 2007; Hess 2013; Blair 2015; Sepinwall 2015). And there is surely more to say.

A genealogy of corporate personhood might unearth fruitful insights for our evolving understanding of corporate agency; and so might thought experiments that reimagine corporate responsibility in a range of possible, and potentially unenviable, futures. These excursions beyond the familiar terrain of business ethics could yield a typology of corporate agents and confirm, or perhaps contradict, the idea that corporate agents must have both rights and responsibilities. Progress can, of course, be made by extending theories already established in the business ethics literature. For instance, original applications of Kantian ethics might enhance our understanding of the connections between corporate agency and individual and collective responsibility.

This objective might likewise be served by novel efforts to match types of responsibility to types of collective. Arguably, considerations of this kind might help us decide where and how to assign blame. When combined with an examination of the identity conditions the legal mind relies on to attribute liability, particularly criminal liability, and historical accounts revealing how legislation and regulation have been subverted by corporations over time; these ideas can improve our comprehension of the extent to which regulation may enable responsible agency, while also helping us imagine the appropriate direction for corporate governance reforms.

These are the worthy objectives pursued by the contributors to this special issue. We have organized their articles around four key themes: agency, responsibility, personhood, and regulation. While many of the articles touch on most, or even all, of these four themes, our grouping is based on what we see as each article's primary contribution.

\section{Agency}

In a strikingly original perspective on corporate agency, Tim Mulgan (University of St. Andrews, UK, and University of Auckland, New Zealand) argues that we need an account that is temporally robust across a range of credible futures. $\mathrm{He}$ asks what future philosophers would think about corporate agency if they were to live in a future broken by climate change and material scarcity, or in a future populated by digital beings that have replaced flesh-and-blood humans. In such a broken or digital future, which no one can be certain will not happen, Mulgan shows that many of the assumptions of contemporary moral theory would no longer hold. He then examines the restrictions these credible futures must place on the theories of corporate agency we would bequeath to the future generations. 
To avoid a future dominated by corporate groups that have no regard for human beings, Mulgan argues, the only temporally robust theory is "moralized extreme collectivism," where morally reliable corporate groups, and only those groups, are recognized as both responsible agents and full moral persons. Morally unreliable groups, by contrast, should be denied agency altogether. As an example of the latter, he notes the disproportionate contribution of business corporations to anthropogenic climate change. Mulgan concludes that we must reorient our thinking about corporate agency and moral reliability before the world is populated by corporate groups whose priorities are entirely divorced from human concerns.

From a very different perspective, Amy MacArthur (High Point University, USA) proposes an innovative theory of Kantian group agency. Although the individual human being is, for Kant, the archetypical moral agent, his recognition of the state as a moral person whose actions are subject to the moral law shows that there is room for a Kantian account of how organized collectives can be held responsible for moral or immoral actions. Using the concepts that inform Kant's theory of individual agency, and drawing on the philosophy of collective intentionality, MacArthur shows that groups, like individuals, can engage in practical deliberation and are able to develop a genuine "group maxim."

For MacArthur, a group maxim, which is not reducible to the sum of the maxims of all the individuals involved, is possible because members can deliberate from a group standpoint that is distinct from their standpoints as particular individuals. Accordingly, moral responsibility should be attributed to the author of the group maxim, that is, to the group itself. MacArthur's contribution to what she calls "agency holism" focuses primarily on formally structured groups, namely those with explicit decision-making procedures. Nevertheless, she suggests, elements of the proposed theory may apply to informal kinds of groups as well.

By contrast, Tobey Scharding (Rutgers University, USA) argues that Kantian ethics cannot hold corporations morally responsible because responsibility is, from a Kantian perspective, inalienable: a corporation cannot be held morally responsible for its members' actions. However, instead of emphasizing what Kant cannot contribute to business ethics, Scharding pursues the alternative implication: business ethicists should use the resources of Kantian ethics to hold individuals, but not corporations themselves, responsible for corporate malfeasance. By focusing on how individuals contribute to actions taken in their organization's name, she provides a model for decomposing business actions into their individual parts and reconstituting them in a context-specific maxim that Kantian ethics can evaluate.

Business ethicists, Scharding argues, should abandon the notion of collective responsibility, and use Kantian ethics, along with other individualistic ethical theories, to evaluate the actions of individual business people. The outcome of this strategy, according to Scharding, is an understanding of ethics that allows business ethics to do what it does best: to guide individuals in value-challenging decisions. For example, through an analysis of the Wells Fargo bogus accounts scandal, she recommends that business ethicists focus on how individual decisions are shaped by the values that underpin their workplaces, rather than on the moral responsibility of the organizations in which they work.

\section{Responsibility}

Moral philosophers, as Stephanie Collins (University of Manchester, UK) observes, are often troubled by the idea of collective responsibility on the grounds that it violates core moral intuitions and principles. Consider the Great Pacific Garbage Patch (GPGP), a vast area in the North Pacific Ocean which is entirely covered by bits of plastic that are likely never fully to disintegrate. Who is responsible for this colossal environmental disaster? Clearly, no individual agent is responsible for the entire GPGP, as any individual contribution is negligible. But to argue for collective responsibility might seem nonsensical as well: after all, if groups are made of individuals, to hold a group responsible means nothing more than to hold their individual members responsible, often for things that they themselves did not do.

Collins counters such critiques by showing that skepticism regarding collective responsibility stems from the failure to distinguish between different kinds of responsibility and different types of collective. There are different kinds of responsibility we might assign to individuals and groups, just as there are different types of collectives that responsibility might be assigned to. Crucially, Collins argues, certain kinds of responsibility may be assigned to certain kinds of collectives in ways that are not reduced to individual responsibility. Although there will be cases where we are unable to attribute the responsibility we might want to, which Collins calls "collective responsibility gaps," we should not take these to be sufficient grounds for rejecting the concept of collective responsibility.

Mihailis Diamantis (University of Iowa, USA) examines a particularly vexing potential responsibility gap, namely the thorny problem of holding corporations criminally liable. As Diamantis explains, one of the core tenets of criminal justice is that the agent that is punished is the agent that committed the crime. But in the case of corporations, which regularly go through "diachronic identity shifts"-including mergers, spin-offs, and acquisitions-it is difficult to identify the agent that committed the crime. If we want our legal system to hold corporate entities criminally liable, we must have a principle that, on the one hand, does not violate our core intuitions about punishing the right agents and, on the 
other hand, does not offer corporate criminals an easy way out through an identity change.

Diamantis draws on ongoing debates in the philosophy of personal identity, cognitive science, and business ethics to offer a conception of diachronic corporate identity which coheres with the corporate "criminal essence theory" he proposes. According to this theory, which Diamantis argues can be defended while remaining neutral on the metaphysics of corporate personhood, a present-day corporation is identical to a past corporate criminal if (and only if) it retains whatever organizational shortcoming that led the past corporation to commit a given crime. As Diamantis shows, this approach is analytically robust, and sits well with our intuitions about corporate identity and responsibility. More importantly, it serves the key purposes of criminal justice, namely retribution, rehabilitation, and deterrence.

\section{Personhood}

The tension between the legal practice of treating corporations as persons and slogans that "corporations are not people," which in the wake of Citizens United stem from the feeling that artificial persons have been allowed to dominate natural persons, is addressed by Jon Garthoff (University of Tennessee, USA). A compelling justification for the moral, and thus legal, priority of natural over artificial persons is sorely needed, and this involves, according to Garthoff, a fundamental revision of the doctrine of legal personhood. Legal personhood should be decomposed into its two main components, "standing" (roughly, the possession of rights) and "liability" (roughly, the possession of obligations), and the expectation that a legal person must have both standing and liability should be qualified.

While some legal persons have both standing and liability, other legal persons have standing but no liability, whereas others still have liability but no standing. For Garthoff, entities with phenomenal awareness, which are able to feel pleasure and pain, have moral standing. But only those with the capacity to think about reasons and justifications, and the capacity to regulate action accordingly, have moral obligations. An infant has rights but no obligations, while an adult in full possession of her faculties has both rights and obligations. Thanks to procedures which constitute group deliberation and group action, corporations have moral obligations, including the duty to meet the legal obligations set by society. But since they lack phenomenal consciousness, corporations lack moral standing. This implies, Garthoff concludes, that they are not suitable holders of constitutional rights.

Setting aside the legitimacy of corporate constitutional rights, Nneka Logan's (Virginia Tech, USA) examination of the racialized roots of corporate personhood is as important as it is timely. Logan argues that the Supreme Court's ruling in the 1886 case of Santa Clara ${ }^{3}$ which extended the Fourteenth Amendment's equal protection clause and, by implication, due process, to corporate property, has had profound implications for race relations in the United States. The Fourteenth Amendment's original intent, Logan writes, was to protect the personhood of freed slaves and their descendants, ensuring their equal treatment before the law, and its extension to corporate personhood devitalized it and helped consolidate corporate power.

American corporations went on to actively oppress generations of African Americans by adopting race-based labor market policies and fostering a managerial identity underpinned by white supremacy. Many discriminations continued even after the Civil Rights movement of the 1960s, and before long affirmative action, a regulatory tool promoting racial redress, was re-conceptualized as diversity management. While diversity management keeps race relations on the corporate radar, it is less concerned with righting the institutional wrongs of the past than with the economic requirements of the organization. A more meaningful understanding of "corporate responsibility to race" is needed. Using recent corporate campaigns as examples, Logan spells out some of the steps to be taken in this direction.

\section{Regulation}

The question of how to best foster responsible corporate agency is the focus of Garrath Williams's (University of Lancaster, UK) contribution. The commonly accepted view that agents lacking the ability to respond to moral reasons are less responsible for their actions produces, Williams points out, a strange result in the corporate context. If culpability and capability go hand in hand, a company with secondrate executives, operating in a poor regulatory environment, would be less responsible for any misdeeds it may commit because of its management's inability to appreciate that better actions were available. Since this conceptual tangle is the product of abstract theorizing about culpability, Williams proposes that we put on our practical hats and think about what holding an agent responsible involves.

It is important to recognize, Williams argues, the social nature of responsibility: varied forms of joint action and cooperation among a plurality of agents that are involved. This does not mean that agents need to have a shared goal or that they deliberately cooperate, but only that their actions mesh within a larger framework which allocates responsibilities and fosters the capacities to fulfill those responsibilities. Regulatory standards, like other ways of defining and

\footnotetext{
3 Santa Clara County v. Southern Pacific R. Co., 118 U.S. 394
} (1886). 
upholding norms, thus play an important role in fostering responsible corporate agency. By creating a shared acknowledgement that some mode of conduct is unacceptable, Williams explains, well-designed and properly enforced regulation "enables" companies to act in ways that are acceptable to society as a whole.

David Ciepley's (University of Denver, USA) take on regulation leads to a different conclusion. While it stands to reason, Ciepley observes, that corporations should provide public benefits in exchange for the privileges which come with incorporation (most notably, entity shielding and limited liability), the history of the corporate form is a story of gradual extrication from responsibility. Charters have long lost their ability to ensure the alignment of corporate interests and the public interest, and our capacity to deter corporate misconduct by brandishing the threat of legal punishment is limited. Fines levied against the legal entity or given natural persons within the corporation, or both, are often ineffective and potentially unjust, and attempts to target corporations qua group agents do not appear to help.

It follows, according to Ciepley, that regulation and punishment, while necessary, will always be insufficient and need to be supplemented by corporate governance reforms which decrease the temptation to engage in misconduct in the first place. It is the corporate control structure, and the associated corporate culture, which requires our utmost attention. Given the questionable impact of existing compliance programs, Ciepley argues, more far-reaching solutions should be on the table. From this perspective, he concludes, Danish-style "industrial foundations," which not only favor long-termism but also direct a portion of their dividends to charity, thereby reinstating the norm that for-profit corporations provide public benefits, hold the most promise.

\section{Future Research}

We hope that readers will find in the ideas offered by these outstanding scholars a source of inspiration for further work. The nine articles in this special issue, taken individually or collectively, identify a number of problems, defend a number of positions and, inevitably, raise many additional questions and puzzles about corporate agency and responsibility. The following, non-exhaustive, list of themes readers might wish to address in ensuing explorations is based on both the contributions to this special issue and our own view of the important avenues for future research.

While recent discussions of corporate agency and responsibility have advanced our understanding of the issues involved we are still some way from a consensus regarding the corporation's moral status. In particular, the issue of corporate moral rights, and their legal protection, will no doubt continue to worry many, not least because of the apparent inconsistency with the basic tenets of a liberal political order. More work attempting to surmount this tension, building on a variety of resources, ranging from normative to applied ethics, and from liberal political thought to institutional economics, is required. Endeavors of this kind will likely need to distinguish between different types of corporate agents, different kinds of legal rights and, more importantly, different reasons for assigning them.

We must also admit that there is a large degree of uncertainty regarding how to deal with groups which do not qualify, in the standard sense, as corporate agents. Many of the problems societies face today, including over-population and environmental degradation, are caused by the indirect and interacting contributions of many individual agents. Understanding patterns of agency across such unstructured groups, and the moral and legal responsibilities that might fall on their members, can help us imagine forwardlooking solutions to these and other challenges. Here, too, the tension with the principles of liberal thought will need to be addressed, and interdisciplinary research into kinds of unstructured groups, types of responsibilities, and once again, different reasons for assigning them, will be valuable.

A final area of concern is how to deal with the emergence of non-human entities, such as robots, electronic agents, and various forms of artificial intelligence. This is no longer merely a possible future; it already is the present. Further research into the parallels to be drawn between corporate agency and the agency of these entities is needed. The question of which legal norms should govern their operation and our relationships with them should also be at the forefront of our investigations. As governments begin to draft legislation clarifying where the liability for harm caused by such entities should lie, the question of how to deal with the likely responsibility gaps is fundamental. Research combining insights from law, philosophy, economics, robotics, and other disciplines will be of paramount importance.

Funding The funding was provided by University of St Andrews School of Management.

\section{References}

Altman, M. (2007). The decomposition of the corporate body: What Kant cannot contribute to business ethics. Journal of Business Ethics, 74(3), 253-266.

Arnold, D. G., Goodpaster, K. E., \& Weaver, G. R. (2016). Past trends and future directions in business ethics and corporate responsibility scholarship. Business Ethics Quarterly, 25(4), v-xv.

Ashman, I., \& Wistanley, D. (2007). For or against corporate identity? Personification and the problem of moral agency. Journal of Business Ethics, 76, 83-95.

Ayer, A. A. (2006). The missing dynamic: Corporations, individuals and contracts. Journal of Business Ethics, 67(4), 393-406.

Beets, S. D. (2011). Critical events in the ethics of U.S. corporation history. Journal of Business Ethics, 102(1), 193-219. 
Black, A. (2002). Guild and state: European political thought from the twelfth century to the present (Revised edn.). New Bruswick: Transaction Publishers.

Blair, M. M. (2013). Corporate personhood and the corporate persona. University of Illinois Law Review, 2013(3), 785-820.

Blair, M. M. (2015). Of corporations, courts, personhood and morality. Business Ethics Quarterly, 25(4), 415-431.

Bowie, N. E. (2017). Business ethics: A Kantian perspective (Second edn.). New York: Cambridge University Press.

Burt, E., \& Mansell, S. (2017). Moral agency in charities and business corporations: Exploring the constraints of law and regulation. Journal of Business Ethics. https://doi.org/10.1007/s1055 1-017-3750-9.

Canning, J. P. (1996). A history of medieval political thought, 3001450. London: Routledge.

Coleman, L. (2014). Corporate identity in Citizens United: Legal fictions and anthropological theory. Political and Legal Anthropology Review, 37(2), 308-328.

Copp, D. (2006). On the agency of certain collective entities: An argument from "Normative Autonomy". Midwest Studies in Philosophy, 30, 194-220.

Danley, J. R. (1999). Corporate moral agency. In R. E. Frederick (Ed.), A companion to business ethics. Oxford: Blackwell.

De George, R. T. (1981). Moral responsibility and the corporation. Philosophic Exchange, 3(2), 41-53.

Deiser, G. F. (1909). The juristic person. University of Pennsylvania Law Review and American Law Register, 57(5), 300-314.

Dempsey, J. (2013). Corporations and non-agential moral responsibility. Journal of Applied Philosophy, 30(4), 334-350.

Donaldson, T. (1982). Corporations and morality. Englewood Cliffs, NJ: Prentice-Hall.

Dubbink, W., \& Smith, J. (2011). A political account of corporate moral responsibility. Ethical Theory and Moral Practice, 14, 223-246.

Erskine, T. (2011). Kicking bodies and damning souls: The danger of harming "Innocent" individuals while punishing "Delinquent" States. In T. Issacs \& R. Vernon (Eds.), Accountability for collective wrongdoing. New York: Cambridge University Press.

French, P. A. (1979). The corporation as a moral person. American Philosophical Quarterly, 16(3), 207-215.

Freund, E. (1897). The legal nature of corporations. Chicago: University of Chicago Press.

Gierke, O. Translated with an Introduction by Maitland, F. W. (1900). Political theories of the middle ages. Cambridge: Cambridge University Press

Gilbert, M. (2002). Collective wrongdoing: Moral and legal responses. Social Theory and Practice, 28(1), 167-187.

Gindis, D. (2016). Legal personhood and the firm: Avoiding anthropomorphism and equivocation. Journal of Institutional Economics, 12(3), 499-513.

Goodpaster, K., \& Matthews, J. (1982). Can a corporation have a conscience? Harvard Business Review, 60(1), 132-141.

Greenfield, K. (2015). In defense of corporate persons. Constitutional Commentary, 30, 309-333.

Greenwood, D. J. H. (2017). Neofeudalism: The surprising foundations of corporate constitutional rights. University of Illinois Law Review, 2017(1), 163-222.

Greenwood, M., \& Freeman, R. E. (2017). Focusing on ethics and broadening our intellectual base. Journal of Business Ethics, $140(1), 1-3$.

Held, V. (2002). Group responsibility for ethnic conflict. Journal of Ethics, 6(2), 157-178.

Hess, K. (2013). If you tickle us... How corporations can be moral agents without being persons. Journal of Value Inquiry, 47(3), 319-335.
Isaacs, T. (2011). Moral responsibility in collective contexts. Oxford: Oxford University Press.

Kurki, V. A. J., \& Pietrzykowski, T. (Eds.). (2017). Legal personhood: Animals, artificial intelligence and the unborn. Cham: Springer.

Lampert, M. (2016). Corporate social responsibility and the supposed moral agency of corporations. Ephemera: Theory and Politics in Organization, 16(1), 79-105.

Laski, H. (1916). The personality of associations. Harvard Law Review, 29(4), 404-426.

List, C., \& Pettit, P. (2011). Group agency: The possibility, design and status of corporate actors. New York: Oxford University Press.

Machen, A. W. (1911). Corporate personality. Harvard Law Review, 24(4), 253-267.

Maitland, F. (1905). Moral personality and legal personality. Journal of the Society of Comparative Legislation, 6(2), 192-200.

Manning, R. C. (1984). Corporate responsibility and corporate personhood. Journal of Business Ethics, 3(1), 77-84.

May, L. (1987). The morality of groups: Collective responsibility, group-based harm and corporate rights. Notre Dame, IN: University of Notre Dame Press.

Miller, S., \& Makela, P. (2005). The collectivist approach to collective moral responsibility. Metaphilosophy, 36(5), 634-651.

Moore, G. (1999). Corporate moral agency: Review and implications. Journal of Business Ethics, 21(4), 329-343.

Moriarty, J. (2016). Business ethics. In E. N. Zalta (Ed.), The stanford encyclopedia of philosophy. https://plato.stanford.edu/entries/ ethics-business.

Néron, P.-Y. (2016). Rethinking the ethics of corporate political activities in a post-citizens united era: Political equality, corporate citizenship and market failures. Journal of Business Ethics, 136(4), $715-728$

Orts, E., \& Smith, N. C. (2017). The moral responsibility of firms. New York: Oxford University Press.

Pasternak, A. (2011). Sharing the costs of political injustice. Politics, Philosophy, Economics, 10(2), 188-210.

Pettit, P. (2007). Responsibility incorporated. Ethics, 117(2), 171-201.

Pfeiffer, R. (1990). The central distinction in the theory of corporate moral personhood. Journal of Business Ethics, 9(6), 473-480.

Phillips, M. (1992). Corporate moral personhood and three conceptions of the corporation. Business Ethics Quarterly, 2(4), 435-439.

Piety, T. S. (2015). Why personhood matters. Constitutional Commentary, 30(2), 361-390.

Pollman, E. (2011). Reconceiving corporate personhood. Utah Law Review, 2011(4), 1629-1675.

Preda, A. (2012). Group rights and group agency. Journal of Moral Philosophy, 9(2), 229-254.

Ripken, S. K. (2011). Corporate first amendment rights after Citizens United: An analysis of the popular movement to end the constitutional personhood of corporations. University of Pennsylvania Journal of Business Law, 14(1), 209-259.

Robinson, Z. (2016). Constitutional personhood. George Washington Law Review, 84(3), 605-667.

Rönnegard, D. (2013). How autonomy alone debunks corporate moral agency. Business and Professional Ethics Journal, 32(1/2), 77-107.

Runciman, D. (1997). Pluralism and the personality of the state. Cambridge: Cambridge University Press.

Sepinwall, A. J. (2015). Denying corporate rights and punishing corporate wrongs. Business Ethics Quarterly, 25(4), 517-534.

Silver, D. (2015). Business ethics after Citizens United: A contractualist analysis. Journal of Business Ethics, 127(2), 385-397.

Stilz, A. (2011). Collective responsibility and the state. Journal of Political Philosophy, 19(2), 190-208.

Stoll, M. L. (2005). Corporate rights to free speech? Journal of Business Ethics, 58(1-3), 261-269. 
Stoll, M. L. (2015). Corporate political speech and moral obligation. Journal of Business Ethics, 132(3), 553-563.

Turner, H. S. (2016). The corporate commonwealth: Pluralism and political fictions in England, 1516-1651. Chicago, IL: University of Chicago Press.

Velasquez, M. (1983). Why corporations are not morally responsible for anything they do. Business \& Professional Ethics Journal, $2(3), 1-18$

Velasquez, M. (2003). Debunking corporate moral responsibility. Business Ethics Quarterly, 13(4), 531-562.
Watson, G. W., Freeman, R. E., \& Parmar, B. (2008). Connected moral agency in organizational ethics. Journal of Business Ethics, 81(2), 323-341.

Wellman, C. (1995). Real rights. Oxford: Oxford University Press.

Werhane, P. (1985). Persons, rights and corporations. Englewood Cliffs, NJ: Prentice-Hall.

Wringe, W. (2012). Collective agents and the communicative theory of punishment. Journal of Social Philosophy, 43(4), 436-456. 